Check for updates

Cite this: Mater. Adv., 2020,

1,814

\section{Synthesis, fluorescence property and cell imaging of a perylene diimide-based NIR fluorescent probe for hypochlorite with dual-emission fluorescence responses $\dagger$}

\author{
Huan-ren Cheng, (DD*a Botao Qu, ${ }^{b}$ Chen Qian, ${ }^{a}$ Meng $X u^{\star c}$ and Ruiping Zhang ${ }^{\star b}$ \\ In this study, for the first time, a novel near-infrared and ratiometric fluorescent probe was conveniently \\ synthesized by reacting PDI-based salicylaldehyde with 2-(hydrazonomethyl)phenol. The probe was designed \\ based on the intramolecular charge transfer (ICT) mechanism and the intramolecular electron transfer (IET) \\ mechanism, which can be blocked by the hypochlorite and a larger conjugation is formed within the probe. \\ Due to the turn-on fluorescence responses triggered by the PET and ICT processes after the $\mathrm{ClO}^{-}$addition, \\ the probe produces simultaneous emission peaks at $600 \mathrm{~nm}$ and $820 \mathrm{~nm}$. In addition, the probe shows a \\ rapid fluorescence response towards the $\mathrm{ClO}^{-}$ions within $5 \mathrm{~s}$, a low detection limit $\left(0.8 \times 10^{-7} \mathrm{M}\right)$, intense \\ color changes (from purple to light green), excellent selectivity, and reversibility. Importantly, cell imaging \\ experiments show that the probe can identify endogenous $\mathrm{ClO}^{-}$successfully.
}

Received 25th March 2020,

DOI: $10.1039 / \mathrm{dOma00131g}$

rsc.li/materials-advances

\section{Introduction}

Fluorescent chemosensors because of their fast detection speed, high sensitivity and simple operation have been widely used in biological tracing, ion detection, environmental protection and other fields. Today, fluorescent chemosensors used as detection tools for toxic ions or small molecules are getting increasing attention. In recent years, a large number of fluorescent sensors for the detection of ions or small molecules have been reported. ${ }^{1-5}$ Among these ions or small molecules, hypochlorite $\left(\mathrm{ClO}^{-}\right)$as a reactive oxygen species plays an important role in our daily life. However, excessive hypochlorite easily causes a variety of diseases. ${ }^{6-8}$ Therefore, it is necessary to develop fluorescent chemosensors for the real-time monitoring of hypochlorous acid/hypochlorite.

To date, numerous fluorescent probes for $\mathrm{ClO}^{-}$have been reported..$^{9-25}$ Most of these fluorescence probes for $\mathrm{ClO}^{-}$were a type of short wavelength response probes. Such probes have some prominent disadvantages, such as strong background effect, shallow imaging depth, and poor anti-infection ability. In order to overcome these defects, near-infrared ratiometric fluorescent probes were developed quickly. ${ }^{26-30}$ Compared with

\footnotetext{
${ }^{a}$ School of Chemical Engineering, Yangzhou Polytechnic Institute,

Yangzhou 225127, China. E-mail: cheng_huanren@163.com

${ }^{b}$ School of Basic Medical Sciences, Shanxi Medical University, Taiyuan 030001, China.E-mail: zrp-7142@163.com

${ }^{c}$ Tongji Medical College, Huazhong University of Science and Technology, Wuhan 430022, China. E-mail: Xumeng@163.com

† Electronic supplementary information (ESI) available. See DOI: 10.1039/ d0ma00131g
}

the common fluorescent probes, near-infrared ratiometric fluorescent probes are overwhelming because of their unique advantages: deeper imaging depth, stronger anti-interference energy, and less tissue damage.

It is known that perylene diimide (PDI) derivatives as excellent fluorophores have been widely studied, most of them are designed based on the PET mechanism, and almost none are designed based on both the PET and ICT mechanism. ${ }^{31-36}$ In this study, a new near-infrared ratiometric fluorescence probe, namely PDI-SY, was successfully designed and easily obtained by a direct condensation reaction between the PDIbased salicylaldehyde and 2-(hydrazonomethyl)phenol (Fig. 1). PDI-SY produces simultaneous emission peaks at $600 \mathrm{~nm}$ and $820 \mathrm{~nm}$, when $\mathrm{ClO}^{-}$is added. In addition, PDI-SY shows high sensitivity and selectivity in a fluorescence "turn-on" manner, the probe can efficiently monitor $\mathrm{ClO}^{-}$with rapid fluorescence responses within $5 \mathrm{~s}$, with a low detection limit $\left(0.8 \times 10^{-7} \mathrm{M}\right)$ and intense color changes (from purple to light green). Further ${ }^{1} \mathrm{H}$-NMR study also suggests that the PET and ICT mechanisms were involved after the addition of $\mathrm{ClO}^{-}$ions. Moreover, the cell imaging experiments show that the probe can identify endogenous $\mathrm{ClO}^{-}$successfully.

\section{Results and discussion}

Synthesis of the probe PDI-SY

The preparation of PDI-SY is shown in Scheme 1, the key intermediate compound PDI-Y was prepared via a simple electrophilic 
<smiles>CCCCN1C(=O)c2ccc3c4c(Oc5ccccc5C=NN=Cc5ccccc5O)cc5c6c(ccc(c7c(Oc8ccccc8C=NN=Cc8ccccc8O)cc(c2c37)C1=O)c64)C(=O)N(CCCC)C5=O</smiles>

Fig. 1 Structure of the probe PDI-SY.

substitution reaction between PDI-S and salicylaldehyde, affording PDI-Y with 95\% yield. All the intermediates and materials used in the synthesis process do not need to be further purified, the materials are cheap and readily available, which greatly reduce the synthesis cost of the probe PDI-SY. All the intermediates and the probe molecule PDI-SY were fully characterized via ${ }^{1} \mathrm{H}$ NMR, ${ }^{13} \mathrm{C} \mathrm{NMR}$, and high-resolution mass spectrometry (HRMS-MALDI-TOF); the detailed synthesis procedure of the PDI-SY has been discussed in the synthesis part.

\section{Ratiometric absorption and dual emission of PDI-SY before and after reaction with $\mathrm{ClO}^{-}$}

The absorption and fluorescence emission properties of PDI-SY $(2 \mu \mathrm{M})$ before and after the reaction with $\mathrm{ClO}^{-}$were studied in an optimized mixture of the PBS buffer solution ( $\mathrm{pH} 7.4)$. All the measurements were carried out in PBS buffer ( $\mathrm{pH}$ 7.4). As shown in Fig. 2, PDI-SY exhibited maximum absorption peaks at around $354 \mathrm{~nm}$ and $556 \mathrm{~nm}$ without any other ions.

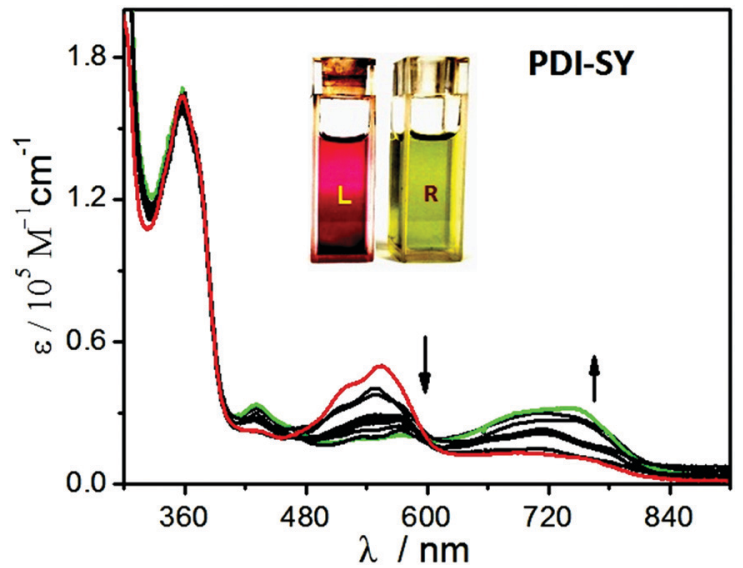

Fig. 2 Ratiometric absorption spectra of PDI-SY as a function of the $\mathrm{ClO}^{-}$ concentration, ([PDI-SY] $=2 \mu \mathrm{M}, V_{\mathrm{THF} / \mathrm{H}_{2} \mathrm{O}}=1: 3, \mathrm{pH}=7.4$, PBS buffer). The inset picture shows the color change of PDI-SY upon the addition of $\mathrm{ClO}^{-}$, L: PDI-SY, R: PDI-SY + $\mathrm{ClO}^{-}$.

Moreover, PDI-SY showed a weak emission at $520 \mathrm{~nm}$, as shown in Fig. 3. However, upon the addition of $\mathrm{ClO}^{-}(0-20 \mu \mathrm{M})$, a new absorption peak at around $720 \mathrm{~nm}$ increased dramatically, while the absorption signals at $556 \mathrm{~nm}$ decreased gradually. When $\mathrm{ClO}^{-}$was added to 2 equivalents, the reaction basically completed, which was concomitant with a remarkable color change from purple to light green, as shown in Fig. 2 inset. Moreover, upon the addition of $\mathrm{ClO}^{-}$, the emission peak at $520 \mathrm{~nm}$ decreased gradually, while a new sharp enhancement of the fluorescence emission at $600 \mathrm{~nm}\left(\Phi_{1 \text { Free }}<0.1, \Phi_{1 \text { Hypochlorite }}=0.58\right)$ and $820 \mathrm{~nm}$ $\left(\Phi_{2 \text { Free }}<0.1, \Phi_{2 \text { Hypochlorite }}=0.18\right)$ was observed, as shown in Fig. 3 . When $\mathrm{ClO}^{-}$was added to 2 equivalents, the reaction was basically completed; the new emission peaks at $600 \mathrm{~nm}$ and $820 \mathrm{~nm}$ reached a maximum value. From the spectral property of PDI-SY, it could be

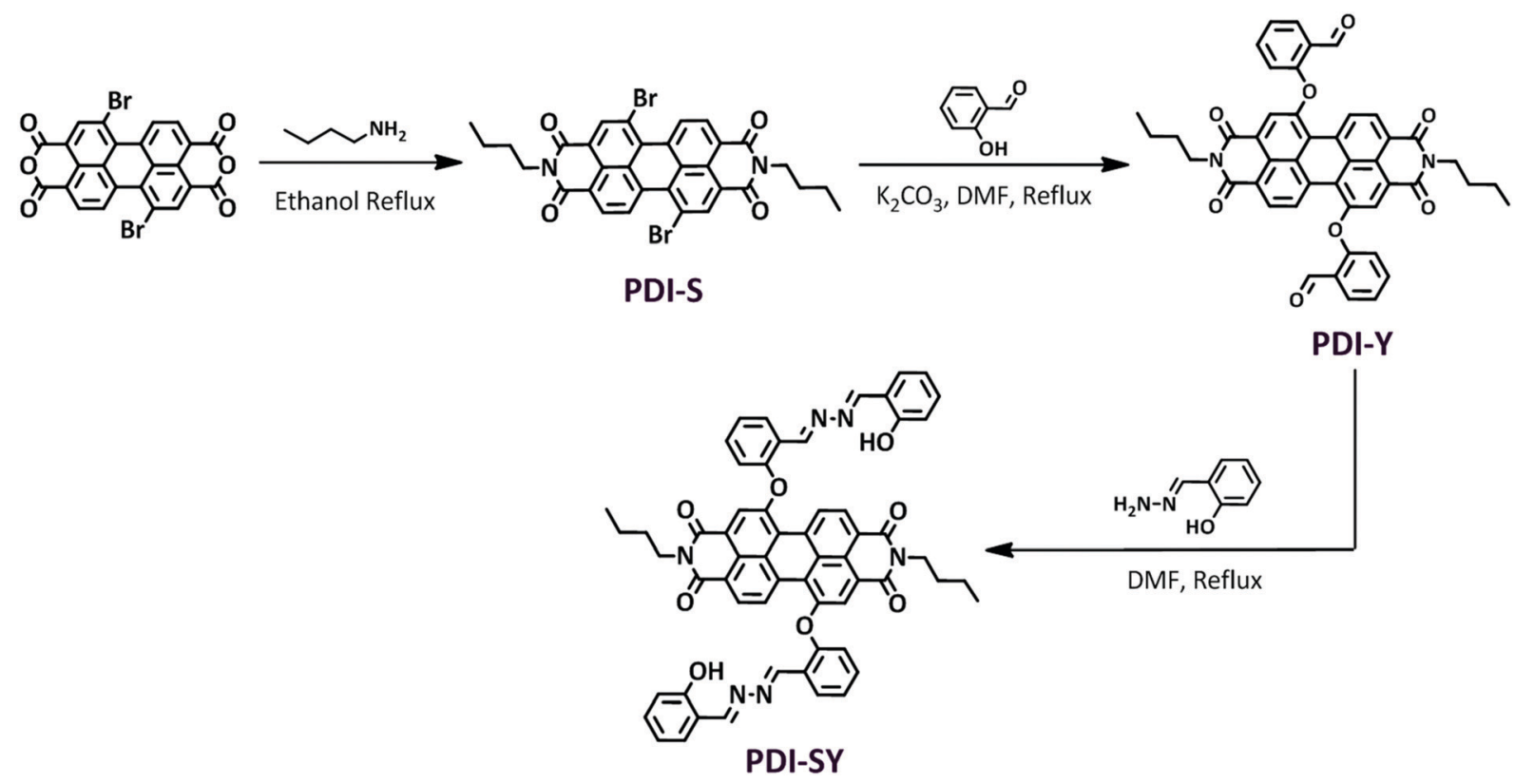

Scheme 1 Synthesis route of the probe PDI-SY. 


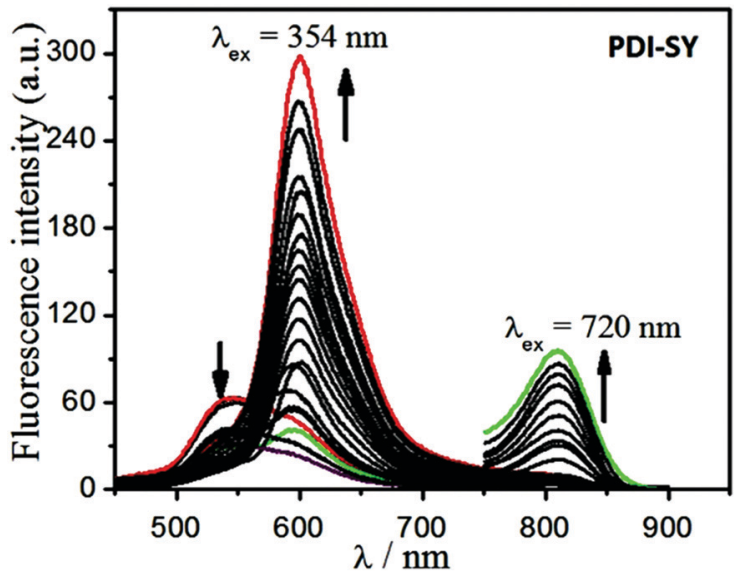

Fig. 3 Dual emission fluorescence spectra of PDI-SY as a function of the $\mathrm{ClO}^{-}$concentration, ([PDI-SY $]=2 \mu \mathrm{M}, \lambda_{\mathrm{ex}}=354 \mathrm{~nm}$ and $720 \mathrm{~nm}, \mathrm{~V}_{\mathrm{THF} / \mathrm{H}_{2} \mathrm{O}}=$ $1: 3, \mathrm{pH}=7.4$, PBS buffer).

confirmed that PDI-SY can be used as a ratiometric fluorescent probe for sensing $\mathrm{ClO}^{-}$.

Moreover, a linear relationship between the concentrations of $\mathrm{ClO}^{-}$and the fluorescence intensity values of PDI-SY at $600 \mathrm{~nm}$ was observed (as shown in Fig. 3), the linear fitting curve of PDI-SY at $600 \mathrm{~nm}$ is shown in Fig. 4. According to this fitted equation, the detection limit of PDI-SY was measured to be $0.8 \times 10^{-7} \mathrm{M}(3 \sigma /$ slope, $\sigma$ is the standard deviation of the blank measurement). The above studies showed that PDI-SY can accurately and sensitively detect $\mathrm{ClO}^{-}$(Table 1 ).

\section{Rapid time responses of PDI-SY for $\mathrm{ClO}^{-}$ions}

The reaction rate of PDI-SY with the $\mathrm{ClO}^{-}$ions is an important parameter to value its real-time tracking capability. As shown in Fig. 5, the reaction of PDI-SY with $\mathrm{ClO}^{-}$can be triggered within $5 \mathrm{~s}$ without stirring, and completed in $60 \mathrm{~s}$ with a maximum emission intensity, indicating that PDI-SY can be employed as a rapid analytical chemosensor for the $\mathrm{ClO}^{-}$detection. Simultaneously, the color of the solution containing PDI-SY changed from purple to light green gradually, as shown in Fig. 5 inset.

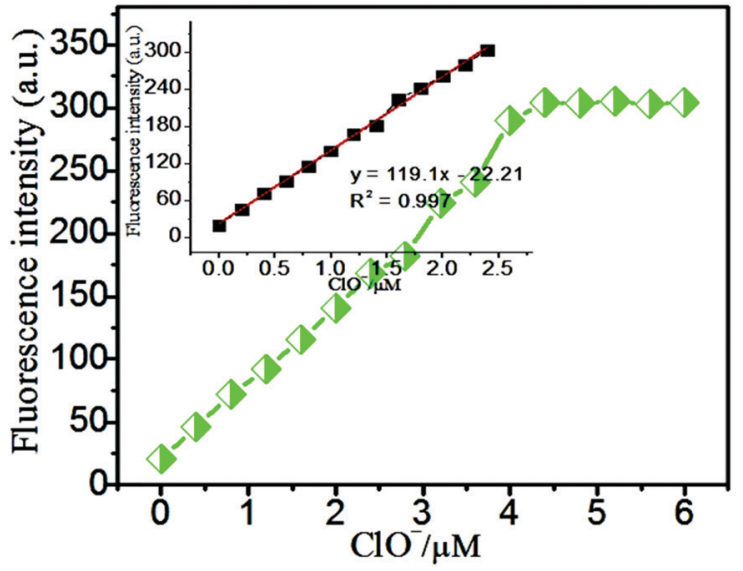

Fig. 4 Linear fitting curve of the probe PDI-SY with $\mathrm{ClO}^{-}$, ([PDI-SY $]=$ $2 \mu \mathrm{M},\left[\mathrm{ClO}^{-}\right]=2$ equivalents, $\left.\lambda_{\mathrm{em}}=600 \mathrm{~nm}, V_{\mathrm{THF} / \mathrm{H}_{2} \mathrm{O}}=1: 3\right)$.
Table 1 Fluorescence properties of PDI-SY in $V_{\mathrm{THF}_{\mathrm{H}} \mathrm{O}} \mathrm{O}=1 / 3$ at $298 \mathrm{~K}$

\begin{tabular}{llllll}
\hline Compounds & $\begin{array}{l}\lambda_{\max }{ }^{a} \\
(\mathrm{~nm})\end{array}$ & $\begin{array}{l}\lambda_{\mathrm{em}}{ }^{b} \\
(\mathrm{~nm})\end{array}$ & $\begin{array}{l}\Delta v_{1} / \Delta \nu_{2}{ }^{c} \\
\left(\mathrm{~cm}^{-1}\right)\end{array}$ & $\begin{array}{l}\Phi_{1}{ }^{d} \text { at } \\
600 \mathrm{~nm}\end{array}$ & $\begin{array}{l}\Phi_{2}{ }^{d} \text { at } \\
820 \mathrm{~nm}\end{array}$ \\
\hline PDI-SY & $354 / 556$ & 600 & 3947 & $<0.1$ & $<0.1$ \\
PDI-SY-ClO $^{-}$ & $556 / 720$ & $600 / 820$ & 1692 & 0.58 & 0.18
\end{tabular}

${ }^{a}$ Absorption maximum. ${ }^{b}$ Emission maximum. ${ }^{c}$ Stoke's shift $=\left(1 / \lambda_{\mathrm{abs}}-\right.$ $\left.1 / \lambda_{\mathrm{em}}\right) \times 10^{7} .{ }^{d}$ Fluorescence quantum yield, the fluorescence quantum yields were determined using rhodamine $6 \mathrm{G}$ and PDI $(\Phi=0.95)$ as a standard, the max absorbance was used as the excited wavelength. ${ }^{37}$

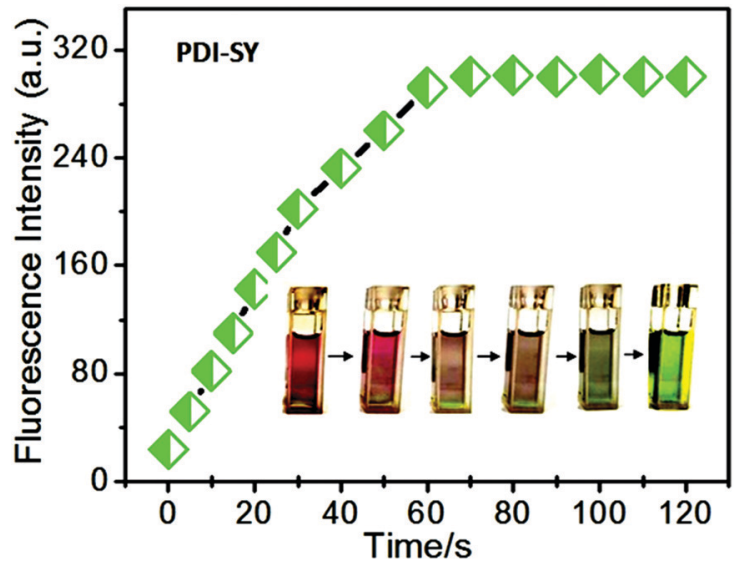

Fig. 5 Time-dependent fluorescence change of PDI-SY $(2 \mu \mathrm{M})$ treated with $\mathrm{ClO}^{-} \cdot \lambda_{\mathrm{ex}}=354 \mathrm{~nm}, \lambda_{\mathrm{em}}=600 \mathrm{~nm}, \mathrm{pH}=7.4$, PBS buffer. (inset: photos of PDI-SY reacted with $\mathrm{ClO}^{-}$ions in waste water from 5 seconds to 120 seconds).

The results demonstrate that PDI-SY has the ability for realtime monitoring of hypochlorite.

\section{Selectivity and reversibility of PDI-SY to various ions}

The interference experiments of the probe PDI-SY with other ions such as $\mathrm{NO}_{2}{ }^{-}, m$-Cl-ph-COOH, glutathione, cysteine, $\mathrm{NO}_{3}{ }^{-}, \mathrm{PO}_{4}{ }^{3-} \mathrm{H}_{2} \mathrm{O}_{2}, \mathrm{Fe}^{3+}, \mathrm{Ag}^{+}, \mathrm{Ba}^{2+}, \mathrm{Co}^{2+}, \mathrm{Ni}^{2+}, \mathrm{Cu}^{2+}, \mathrm{Zn}^{2+}$, $\mathrm{Cd}^{3+}, \mathrm{Pb}^{2+}, \mathrm{Mn}^{2+}$ and $\mathrm{Fe}^{2+}$ were taken into account. First, eighteen parts of the PDI-SY solution with the same concentration were prepared. Then, the other ions were added to the solution, respectively. The fluorescence spectra of PDI-SY at $600 \mathrm{~nm}$ were collected. At last, $\mathrm{ClO}^{-}$ions were added to the mixed solutions of PDI-SY with the other ions. All the fluorescence spectra excited at $354 \mathrm{~nm}$ were collected. As shown in Fig. 6, none of the other ions caused any fluorescence emission, while an obvious fluorescence enhancement occurred only after the addition of $\mathrm{ClO}^{-}$, indicating that PDI-SY can detect $\mathrm{ClO}^{-}$ specifically.

PDI-SY shows good reversibility to $\mathrm{ClO}^{-}$(as oxidant) and $\mathrm{S}^{2-}$ (as a reducing agent); the reversibility experiment was carried out by recording the emission intensity of PDI-SY at $600 \mathrm{~nm}$ with respect to the change of the ions $\mathrm{ClO}^{-} / \mathrm{S}^{2-}$ up to 5 cycles. Fig. 7 shows the fluorescence intensity change of PDI-SY for 5 cycles. The relative standard deviations from five replicates were estimated to be $<2 \%$. 


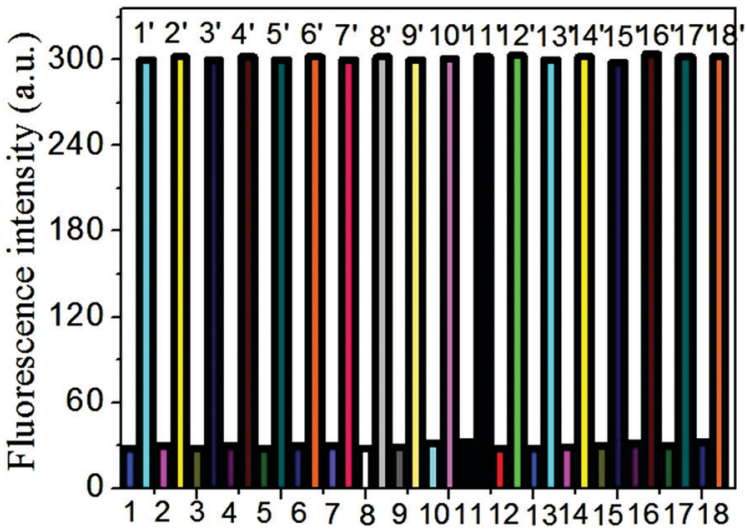

Fig. 6 Fluorescence spectra of the probe PDI-SY to numerous metal cations such as: $(1-18) \mathrm{NO}_{2}^{-}, m-\mathrm{Cl}-\mathrm{ph}-\mathrm{COOH}$, glutathione, cysteine, $\mathrm{NO}_{3}{ }^{-}, \mathrm{PO}_{4}{ }^{3-} \mathrm{H}_{2} \mathrm{O}_{2}, \mathrm{Fe}^{3+}, \mathrm{Ag}^{+}, \mathrm{Ba}^{2+}, \mathrm{Co}^{2+}, \mathrm{Ni}^{2+}, \mathrm{Cu}^{2+}, \mathrm{Zn}^{2+}, \mathrm{Cd}^{3+}, \mathrm{Pb}^{2+}$, $\mathrm{Mn}^{2+}$ and Fe ${ }^{2+},[\mathrm{PDI}-\mathrm{SY}]=2 \mu \mathrm{M}, \lambda_{\mathrm{ex}}=354 \mathrm{~nm}, \lambda_{\mathrm{em}}=600 \mathrm{~nm}, V_{\mathrm{THF} / \mathrm{H}_{2} \mathrm{O}}=1 / 3$, $\mathrm{pH}=7.4$, PBS buffer

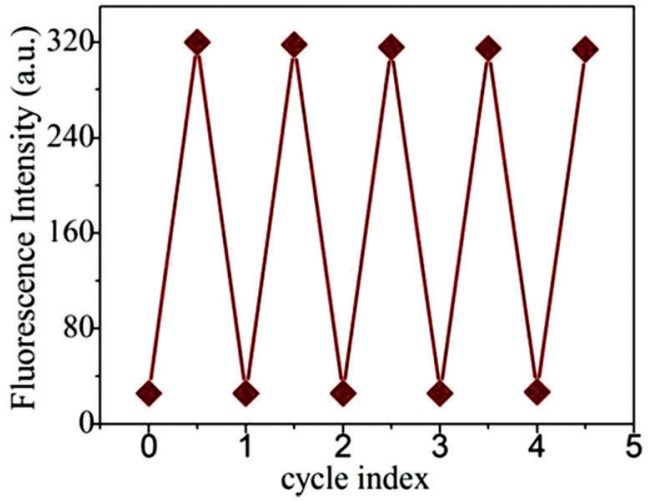

Fig. 7 Fluorescence intensity of PDI-SY at $600 \mathrm{~nm}$ ([PDI-SY] $=2 \mu \mathrm{M}, \lambda_{\mathrm{ex}}=$ $354 \mathrm{~nm}$, in $V_{\mathrm{THF} / \mathrm{H}_{2} \mathrm{O}}=1: 3, \mathrm{pH}=7.4$, PBS buffer) upon addition of $\mathrm{ClO}^{-}$ (2 equiv.) and $\mathrm{S}^{2-}$ solution up to 5 cycles.

\section{PET and ICT-based mechanism discussion of PDI-SY with ClO} ions

The possible mechanism of the PDI-SY reaction with the $\mathrm{ClO}^{-}$ions is shown in Fig. 8, a PET process from the dibenzyliden-ehydrazine to the PDI core in the excited PDI-SY blocks the fluorescence emission of the PDI core. After the addition of the $\mathrm{ClO}^{-}$ions, an oxidation reaction between PDI-SY and $\mathrm{ClO}^{-}$ions occurred. The

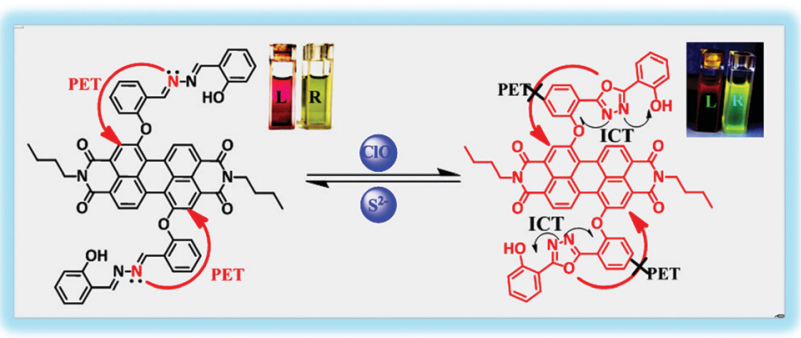

Fig. 8 The possible mechanism based on the PET and ICT of PDI-SY for detecting $\mathrm{ClO}^{-}$ions.

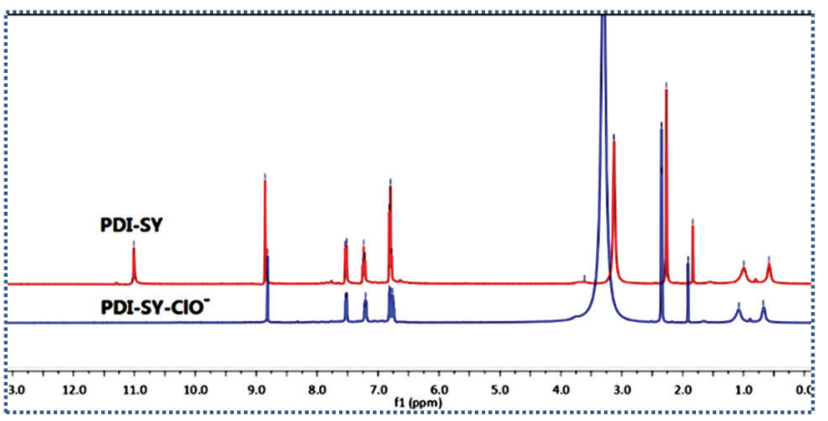

Fig. $9{ }^{1} \mathrm{H}$ NMR spectra of PDI-SY in the absence (top) and presence (bottom) of two equiv. of $\mathrm{ClO}^{-}$in deuterated $\mathrm{DMSO}-d_{6}$.

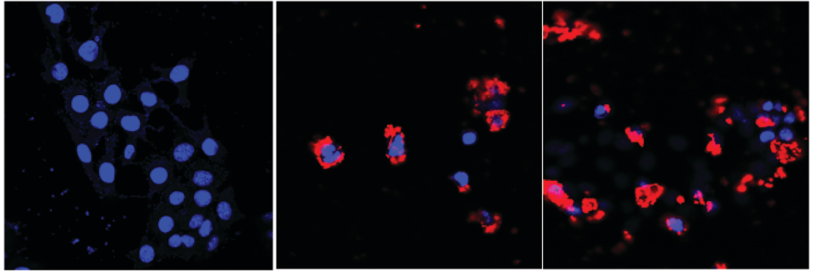

Fig. 10 Confocal laser scanning microscopy images of 4T1 cells incubated with PDI-SY $(5 \mu \mathrm{M})$ for 30 min (left) and then further incubated with $\mathrm{NaClO}(10 \mu \mathrm{M})$ for $30 \mathrm{~min}$ (middle and right). Blue channel: $\lambda_{\mathrm{ex}}=358 \mathrm{~nm}$; red channel: $\lambda_{\text {ex }}=456 \mathrm{~nm}$.

result of the oxidation reaction produces a new 1,3,4-oxadiazole ring that increases the conjugate plane of the new molecule, blocking the PET process in the probe, and producing the ICT process. Thus, the fluorescence of the probe recovered, and a new absorption peak at $720 \mathrm{~nm}$ appeared. Moreover, the reaction mechanism of PDI-SY with the $\mathrm{ClO}^{-}$ions has been proved by ${ }^{1} \mathrm{H}$ NMR. As shown in Fig. 9, the ${ }^{1} \mathrm{H}$ NMR shifts of $\mathrm{C}=\mathrm{N}-\mathrm{H}$ in the probe is $11.0 \mathrm{ppm}$. However, after two equiv. of $\mathrm{ClO}^{-}$was added, the peak at $11 \mathrm{ppm}$ disappeared completely; simultaneously, no other new peak appeared. This change of ${ }^{1} \mathrm{H}$ NMR combined with the spectral property of PDI-SY strongly proves the possible mechanism of PDI-SY for the detection of $\mathrm{ClO}^{-}$ions, as shown in Fig. 8. This discussion above is helpful for us to develop some new probes in the follow-up research work.

Confocal laser scanning microscopy images of PDI-SY with 4T1 cells

$4 \mathrm{~T} 1$ cells $(\approx 10000$ cells per well) plated on a $96-$ well plate were cultured in fresh media that contained $10 \%$ fetal calf serum. PDI-SY at various concentrations was added and cultivated at $37^{\circ} \mathrm{C}$ for $0.5 \mathrm{~h}$. Then, $20 \mu \mathrm{l}$ of NaClO $(10 \mu \mathrm{M})$ was added to the well for $30 \mathrm{~min}$. The CLSM imaging was performed on an Olympus FLUOVIEW FV1000 confocal laser scanning microscope. The cell nuclei were stained with DAPI (blue) and the cytoplasms were stained with NaClO modified PDI-SY (red), as shown in Fig. 10.

\section{Conclusions}

In summary, a near-infrared and ratiometric fluorescent probe PDI-SY designed on the PET and ICT mechanism, which 
features a robust fluorescence "light-up" responses to $\mathrm{ClO}^{-}$ was successfully synthesized and PDI-SY was fully characterized by ${ }^{1} \mathrm{H}$ NMR, ${ }^{13} \mathrm{C}$ NMR, and high-resolution mass spectrometry. The probe can efficiently monitor $\mathrm{ClO}^{-}$with rapid spectral responses within $5 \mathrm{~s}$, low detection limit $\left(0.8 \times 10^{-7} \mathrm{M}\right)$ and intense color changes (from purple to light green). In addition, PDI-SY can be used to detect the hypochlorite for 5 cycles, the new detection mechanism of PDI-SY for $\mathrm{ClO}^{-}$ions was proved by ${ }^{1} \mathrm{H}$ NMR for the first time. More importantly, the application of $\mathrm{ClO}^{-}$detection in cell imaging has also been achieved. Therefore, we expect that PDI-SY may provide a new strategy for the detection of $\mathrm{ClO}^{-}$in biological application.

\section{Experimental}

\section{Materials and methods}

${ }^{1} \mathrm{H}$ NMR and ${ }^{13} \mathrm{C}$ NMR spectra were recorded on a Bruker ADVANCE 300 NMR spectrometer in $\mathrm{CDCl}_{3}$ or DMSO. HRMS were recorded on an Ultraflex II MALDI-TOF mass spectrometer. UV-visible absorption spectra were recorded on a Shimadu UV-3600 spectrophotometer. Fluorescence spectra were recorded on a HORIBA FL-4 Max spectrometer. FT-IR spectra were recorded on a Nicolet 750 series in the region of $4000-400 \mathrm{~cm}^{-1}$. The CLSM imaging was performed on Olympus FLUOVIEW FV1000 confocal laser scanning microscope. All the reagents used were purchased from Aladdin. The solvent used in the test was PBS buffer.

\section{Synthesis}

Compound 2-(hydrazonomethyl)phenol was prepared our laboratory according to the modified published methods. ${ }^{38}$ The structure of the compounds PDI-S, PDI-Y and the compound PDI-SY was characterized by ${ }^{1} \mathrm{H}$ NMR and their spectra have been displayed in the ESI. $\dagger$

Compound PDI-S. Compound 1,7-bis(4-tert-butylphenyloxy)perylene-3,4:9,10-tetracar-boxylic acid bisanhydride (4.0 g, $7.3 \mathrm{mmol})$, and $n$-butylamine $(0.53 \mathrm{~g}, 1.5 \mathrm{mmol})$ was dissolved in ethanol $(80 \mathrm{ml})$, the mixture was heated under reflux for $12 \mathrm{~h}$. After cooled to room temperature, the solvent was removed under reduced pressure, a red-black solid was observed, which was washed with water $(100 \mathrm{ml})$ and dried in $60{ }^{\circ} \mathrm{C}$. It was used for the next reaction without further purification. ${ }^{1} \mathrm{H}$ NMR (DMSO, ppm): $\delta 8.67-8.65(\mathrm{~d}, 3 \mathrm{H}, J=6 \mathrm{~Hz}), 8.46-8.44(\mathrm{~d}, 3 \mathrm{H}$, $J=6 \mathrm{~Hz}), 4.15-4.10(\mathrm{~m}, 4 \mathrm{H}), 1.96-1.95$ (m, 2H), 1.41-1.23 (m, 6H), 0.97-0.90 (m, 6H).

Compound PDI-Y. In $\mathrm{N}_{2}$ atmosphere, compound PDI-S (3.0 g, $4.5 \mathrm{mmol})$, o-hydroxybenzaldehyde $(1.1 \mathrm{~g}, 9 \mathrm{mmol})$, $\mathrm{K}_{2} \mathrm{CO}_{3}(1.5 \mathrm{~g}, 15 \mathrm{mmol})$, and DMF $(40 \mathrm{ml})$ were mixed and the mixture was heated at $100{ }^{\circ} \mathrm{C}$ for $8 \mathrm{~h}$. After cooled to the room temperature, water $(40 \mathrm{ml})$ was added and the $\mathrm{pH}$ value was adjusted to weak acidic using $1 \mathrm{~N}$ hydrochloric acid resulting in the precipitation of black solid. Subsequently it was dried in a vacuum drying oven at $50{ }^{\circ} \mathrm{C}$ for 24 hours, to give a yellow solid $3.2 \mathrm{~g}$, yield: $95 \%$. It was used for the next reaction without further purification. ${ }^{1} \mathrm{H}$ NMR (DMSO, ppm): $\delta 10.25(\mathrm{~s}, 2 \mathrm{H}), 8.99(\mathrm{~s}, 4 \mathrm{H})$,
7.99-7.94 (m, 2H), 7.64-7.52 (m, 3H), 7.49-7.25 (m, 3H), 6.97-6.94 $(\mathrm{m}, 6 \mathrm{H}), 4.15-4.10(\mathrm{~m}, 4 \mathrm{H}), 1.98-1.96(\mathrm{~m}, 2 \mathrm{H}), 1.41-1.23(\mathrm{~m}, 6 \mathrm{H})$, 0.97-0.90 (m, 6H). TOF-MS-ES: $m / z$. Calculated: $[\mathrm{M}+\mathrm{H}]^{+}=$ 743.238, found: $[\mathrm{M}+\mathrm{H}]^{+}=743.236$.

Compound PDI-SY. Compound PDI-Y (2.0 g, $2.7 \mathrm{mmol})$, compound salicylhydrazine $(5.9 \mathrm{mmol}$ excess $)$, and DMF $(60 \mathrm{ml})$ was mixed, the mixture was heated at $80{ }^{\circ} \mathrm{C}$ for $12 \mathrm{~h}$. After cooled to room temperature, water $(60 \mathrm{ml})$ was added resulting in the precipitation of a black solid which was filtrated and dried in a blast drying oven at $60{ }^{\circ} \mathrm{C}$. Then, it was purified via recrystallization by ethanol to give a black solid 2.9 g, yield: 92\%. FT-IR (KBr) cm ${ }^{-1}: 3452(\nu \mathrm{C}=\mathrm{C}-\mathrm{H}) ; 2932-2980$ $(\nu \mathrm{C}-\mathrm{H}) ; 1602\left(\nu_{\mathrm{as}} \mathrm{H}-\mathrm{C}=\mathrm{C}\right) 1498\left(\nu_{\mathrm{s}}-\mathrm{C}=\mathrm{C}\right) 1276(\nu \mathrm{C}-\mathrm{O}) .{ }^{1} \mathrm{H}$ NMR (DMSO, ppm): $\delta 11.12(\mathrm{~s}, 4 \mathrm{H}), 8.99(\mathrm{~s}, 4 \mathrm{H}), 7.68(\mathrm{~m}, 5 \mathrm{H}), 7.42-$ $7.38(\mathrm{t}, 5 \mathrm{H}, J=6 \mathrm{~Hz}), 6.99-6.95(\mathrm{~m}, 10 \mathrm{H}), 3.86-3.80(\mathrm{~m}, 4 \mathrm{H}), 2.07$ (m, 2H), $1.25(\mathrm{~m}, 6 \mathrm{H}), 0.88(\mathrm{~m}, 6 \mathrm{H}) .{ }^{13} \mathrm{C}$ NMR (DMSO, ppm): $\delta$ 192.17, 162.78, 161.20, 136.89, 129.65, 122.76, 117.69, 36.25, 31.24, 22.97, 14.39. TOF-MS-ES: $m / z$. Calculated: $[\mathrm{M}+\mathrm{H}]^{+}=$ 979.3450, found: $[\mathrm{M}+\mathrm{H}]^{+}=979.3450$.

\section{Conflicts of interest}

There are no conflicts to declare.

\section{Acknowledgements}

This work was supported by PhD Botao Qu for confocal laser scanning cell images, the "Qinglan project" of Jiangsu Province (2018-2012) College of Chemistry and Chemical Engineering, Yangzhou Polytechnic Institute, the Fundamental Research Funds for the National Natural Science Foundation of China (No. 51372077), and the Natural Science Foundation of Shanxi Province (No. 201901D111213).

\section{References}

1 Y. Y. Zhang, Y. F. Ma, Z. Wang, X. Y. Zhang, X. Chen and H. M. Wang, Analyst, 2020, 145, 939-945.

2 X. J. He, C. C. Xu, W. Xiong, Y. Qian, J. Y. Fan, F. Ding, H. Deng, H. Chen and J. L. Shen, Analyst, 2020, 145, 29-33.

3 Y. P. Pan, Y. Yan, Y. Li, X. W. Gao and D. B. Chao, New J. Chem., 2019, 43, 15120-15125.

4 S. Malkondu, S. Erdemir and S. Karakurt, Dyes Pigm., 2020, 174, 108019.

5 X. P. Lin, Y. L. Chen, L. Bao, S. J. Wang, K. Y. Liu, W. D. Qin and F. G. Kong, Dyes Pigm., 2020, 174, 108113.

6 G. C. Bittner, C. R. Bertozzi and C. J. Chang, J. Am. Chem. Soc., 2013, 135, 1783-1795.

7 K. B. Li, L. Dong, S. Zhang, W. Shi, W. P. Jia and D. M. Han, Talanta, 2017, 165, 593-597.

8 N. Güngör, A. M. Knaapen, A. Munnia, M. Peluso, G. R. Haenen, R. K. Chiu, R. W. L. Godschalk and F. J. Van Schooten, Mutagenesis, 2010, 25, 149-154.

9 Y. C. Du, B. W. Wang, D. Jin, M. R. Li, Y. Li, X. L. Yan, X. Q. Zhou and L. G. Chen, Anal. Chim. Acta, 2019, 12, 23. 
10 C. P. Jiao, Y. Y. Liu, W. J. Lu, P. P. Zhang, X. Ma and Y. F. Wang, RSC Adv., 2019, 9, 31196-31201.

11 M. R. Li, F. K. Du, P. Xue, X. C. Tan, S. G. Liu, Y. Zhou, J. Chen and L. J. Bai, Spectrochim. Acta, Part A, 2020, 227, 117760.

12 J. Lv, F. Wang, T. W. Wei and X. Q. Chen, Ind. Eng. Chem. Res., 2017, 56, 3757-3764.

13 W. J. Shi, Y. Huang, W. C. Liu, D. Xu, S. T. Chen, F. G. Liu, J. Q. Hu, L. Y. Zheng and K. Chen, Dyes Pigm., 2019, 170, 107566.

14 X. H. Xu, C. Liu, Y. Mei and Q. H. Song, J. Mater. Chem. B, 2019, 7, 6861-6867.

15 X. L. Zhong, Q. Yang, Y. S. Chen, Y. L. Jiang, B. X. Wang and J. Shen, J. Mater. Chem. B, 2019, 7, 7332-7337.

16 J. S. Lan, L. Liu, R. F. Zeng, Y. H. Qin, Y. Liu, X. Y. Jiang, A. Aihemaiti, Y. Ding, T. Zhang and R. J. Y. Hoc, Chem. Commun., 2020, 56, 1219-1222.

17 G. J. Mao, G. Q. Gao, Z. Z. Liang, Y. Y. Wang, L. Su, Z. X. Wang, H. Zhang, Q. J. Ma and G. S. Zhang, Anal. Chim. Acta, 2019, 1081, 184-192.

18 M. Ren, Z. H. Li, J. Nie, L. Wang and W. Y. Lin, Chem. Commun., 2018, 54, 9238-9241.

19 D. Wu, L. Y. Chen, Q. L. Xu, X. Q. Chen and J. Y. Yoon, Acc. Chem. Res., 2019, 52, 2158-2168.

20 Y. L. Pak, S. J. Park, Q. L. Xu, H. Myung Kim and J. Yoon, Anal. Chem., 2018, 90, 9510-9514.

21 L. Wang, X. L. Chen, Q. Xia, R. Y. Liu and J. Q. Qu, Ind. Eng. Chem. Res., 2018, 57, 7735-7741.

22 Y. V. Zatsikha, N. O. Didukh, R. K. Swedin, V. P. Yakubovskyi, T. S. Blesener, A. T. Healy, D. E. Herbert, D. A. Blank, V. N. Nemykin and Y. P. Kovtun, Org. Lett., 2019, 21, 5713-5718.

23 B. L. Huo, M. Du, A. Shen, M. W. Li, Y. R. Lai, X. Bai, A. J. Gong, L. Q. Fang and Y. X. Yang, Sens. Actuators, B, 2019, 284, 23-29.
24 Y. L. Zhu, K. N. Wang, X. W. Wu, Y. N. Sun, X. S. Gong, D. X. Cao, R. F. Guan and Z. Q. Liu, Talanta, 2020, 209, 120548.

25 Y. F. Huang, Y. B. Zhangb, F. J. Huob, J. B. Chaob and C. Yin, Sens. Actuators, B, 2019, 287, 453-458.

26 Y. L. Wu, J. Wang, F. Zeng, S. L. Huang, J. Huang, H. T. Xie, C. M. Yu and S. Z. Wu, ACS Appl. Mater. Interfaces, 2016, 8(2), 1511-1519.

27 C. DuanMiae, W. VerwilstJunchao, X. Seok, K. Zeng and J. S. Kim, Anal. Chem., 2019, 91(6), 4172-4178.

28 X. M. Zou, X. B. Zhou, C. Cao, W. Y. Lu, W. Yuan, Q. Y. Liu, W. Feng and F. Y. Li, Nanoscale, 2019, 11, 2959-2965.

29 C. Xu, Y. Qian, Z. Q. Qi, C. G. Lu and Y. P. Cui, New J. Chem., 2018, 42, 6910-6917.

30 Y. Y. Zhang, Y. F. Ma, Z. Wang, X. Y. Zhang, X. Chen, S. C. Hou and H. M. Wang, Analyst, 2020, 145, 939-945.

31 H. B. Gobeze, L. M. Arellano, A. M. Gutiérrez-Vílchez, M. J. Gómez-Escalonilla, Á. Sastre-Santos, F. FernándezLázaro, F. Lang and F. D’Souz, Nanoscale Adv., 2019, 1, 4009-4015.

32 W. Zhang, Y. Song, S. J. He, L. Shang, R. N. Ma, L. P. Jia and H. S. Wang, Nanoscale, 2019, 11, 20910-20916.

33 Y. X. Zhou, B. Xue, C. Y. Wu, S. Q. Chen, H. Liu, T. G. Jiu, Z. B. Li and Y. J. Zhao, Chem. Commun., 2019, 55, 13570-13573.

34 M. Li, J. Xu, W. F. Guo, W. C. Zhong, Q. Li, L. L. Tan and L. Shang, Sens. Actuators, B, 2020, 305, 127422.

35 P. Singh, L. S. Mittal, K. Kumar, P. Sharma, G. Bhargava and S. Kumara, Chem. Commun., 2018, 54, 9482-9485.

36 K. Kumar, S. Kaur, S. Kaur, G. Bhargava, S. Kumar and P. Singh, J. Mater. Chem. B, 2020, 8, 125-135.

37 J. N. Demas and G. A. Crosby, J. Phys. Chem., 1971, 75, 991-1024.

38 B. Gregory, L, N. Donna $\mathrm{M}$ and J. Branko S, Bioorg. Med. Chem., 2014, 22(17), 4629-4636. 